Annals of Warsaw University of Life Sciences - SGGW

Land Reclamation No 42 (2), 2010: 249-259

(Ann. Warsaw Univ. of Life Sci. - SGGW, Land Reclam. 42 (2), 2010)

\title{
Application of permeable reactive barriers near roads for chloride ions removal
}

\author{
JOANNA FRONCZYK, KATARZYNA PAWLUK, MARTA MICHNIAK \\ Department of Geotechnical Engineering, Warsaw University of Life Sciences - SGGW
}

\begin{abstract}
Application of permeable reactive barriers near roads for chloride ions removal. One of the most critical sources of pollutants are road run-offs. Road run-off is a complex mixture of toxicants e.g. heavy metals, de-icing agents, organic compounds and water suspensions of solid substances. One of the most negative impact on the environment has sodium chloride which is used as de-icing agent. In the case of incorrect environment protection in the vicinity of roads pollutants may migrate to groundwater causing hazard to sources of potable water. One of the methods to prevent the migration of pollutants to groundwater is imposing the flow of polluted water through a reactive material filling a permeable reactive barrier (PRB). This paper examines the feasibility of selected reactive materials for the reduction chlorides concentration in road run-offs. Four different reactive materials: zero valent-iron, activated carbon, zeolite and geza rock have been chosen for studies. The tests results indicated that the most popular reactive materials used in PRB technology, activated carbon and zero-valent iron, removed exhibited the highest efficiency in chloride ions removal. Moreover, the composition of road run-off in samples collected along roads in Warsaw was determinated.
\end{abstract}

Key words: Permeable Reactive Barrier, reactive materials, remediation, contamination, de-icing agents.

\section{INTRODUCTION}

Process of degradation and destruction of the environment is in mostly caused by human negative activities, especially in view of generating sources of pollution.
Road infrastructure is one of the sources of this type of contamination. Transport has a highly negative impact on surfaceand groundwater, soil and air in the vicinity of roads. Pollution can be caused by the emission of fuel gases, evaporation of media, breaks and tires usage, as well as de-icing agents (Merkisz et al. 2005). The most widely used de-icing material is sodium chloride $\mathrm{NaCl}$, which dissociates in water to $\mathrm{Na}^{+}$and $\mathrm{Cl}^{-}$thereby reducing its freezing temperature.

Although natural attenuation processes occur in the soil reducing the concentration of contaminants (by degradation, dilution or sorption), of high contamination of soil and groundwater necessitates the application of remediation methods (Yong and Mulligan 2004). One of technical methods which are used to reduce concentrations of substances contaminated groundwater is Permeable Reactive Barriers (PRB) (Fig. 1). "A permeable reactive barrier is a wall built below ground to clean up polluted groundwater. The wall is permeable, which means it has tiny holes that allow groundwater to flow through it. Reactive materials in the wall trap harmful chemicals or change the chemicals into harmless ones. Clean groundwater flows out the other side of the wall" (EPA 542-F-01-005 April 2001). 


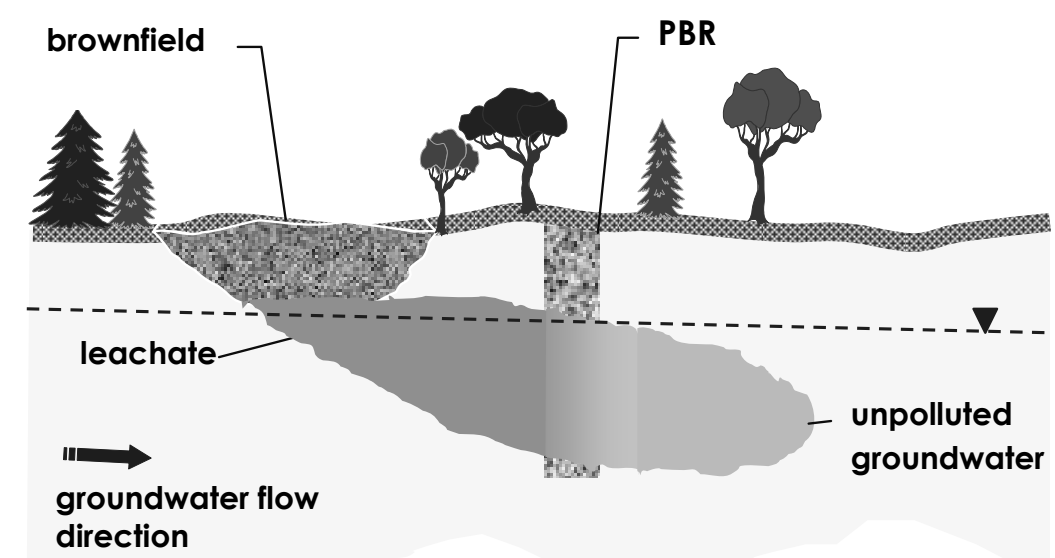

FIGURE 1. The concept of Permeable Reactive Barrier (Fronczyk 2008)

PRBs are widely used in contaminated areas (like brownfields) and have a lot of advantages such as relatively low costs, the usage of naturally occurring processes in groundwater, low impact on the environment and the possibility of implementation in urbanized areas. However, the PRBs have disadvantages like: long remediation time, changes the properties of reactive material in time and the need for regeneration or exchange of reactive materials.

The aim of this paper is to study the suitability of some chosen materials (activated carbon, zeolite, zero-valent iron, geza rock) as fillers for PRBs designated for protection of groundwater along roads.

\section{CONTAMINANTS FROM TRANSPORT}

Transport is one of the sources of environment pollution. The highest concentration of contaminants occurs in the vicinity of roads. The level of contamination depends on some factors, e.g. physicochemical properties of soils, amount of absorbed chemical substance, distance from emission source and size of contaminant plume.

Properties of soils decide about intensity of natural attenuation processes and contaminants migration in soil layers. One of the most important factor is hydraulic conductivity $k$. In subsoils, many factors can influence the hydraulic conductivity, e.g., any increase in double layer thickness produces a decrease in hydraulic conductivity, also any increase in electrolyte concentration or an increase in cation valence will tend to decrease hydraulic conductivity. However, clayey soils permeated with liquids containing monovalent cations tend to produce low hydraulic conductivity while those permeated with liquids containing polyvalent cations tend to produce higher hydraulic conductivity of clayey soils. On the other hand, turbidity, nutrient content, and microorganisms can also affect hydraulic conductivity (Daniel 1994). In case of non-cohesive soils, there exist two transport mechanisms: advection and dispersion. There is also third 
transport mechanism, diffusion, which appears in case of cohesive soils (but no occurs advection process). Migration of pollutants in soils causes contamination of water and air, as well as has negative impact on plants and animals. Moreover, the sorption capacity of soils influences intensity of contaminants migration: the highest sorption capacity, the lowest migration intensity.

Main contaminants from transport are (Polkowska et al. 2007):

- nitrogen oxides,

- carbon monoxide,

- hydrocarbons,

- particulate matter PM,

- sulfur oxides,

- aldehydes,

- salt.

Most of these substances are connected with engine gases, in contrast to salt which is used to safe driving conditions during winter season. The rate of salt application is about thousands of tones per year. The most common de-icing material is sodium chloride $(\mathrm{NaCl})$ because of its low cost, availability and high effectiveness. $\mathrm{NaCl}$ can be used in form of dry salt but also as brine, pre-wetted salt or mixed with calcium chloride (IBDiM 2006). Furthermore, there are standards recommending the exact dose of $\mathrm{NaCl}$ which should be adjusted depending on weather conditions. In the compact city environment with high traffic density, street trees commonly are stressed due to a harsh microclimate and soil conditions (e.g. inhibition of membranes functions, ion deficiency, decrease of enzymes activity, salt-induced water stress). The use of de-icing salts on roads also leads to deposition in the greenery environment (Cekstere et al. 2008).

\section{MATERIALS}

Materials used in the research are divided into two following groups:

- reactive materials,

- de-icing agents.

The reactive materials used should provide facilitate the reduction of concentration harmful substances. In conducted investigations four materials were taken into account (Fig. 2):

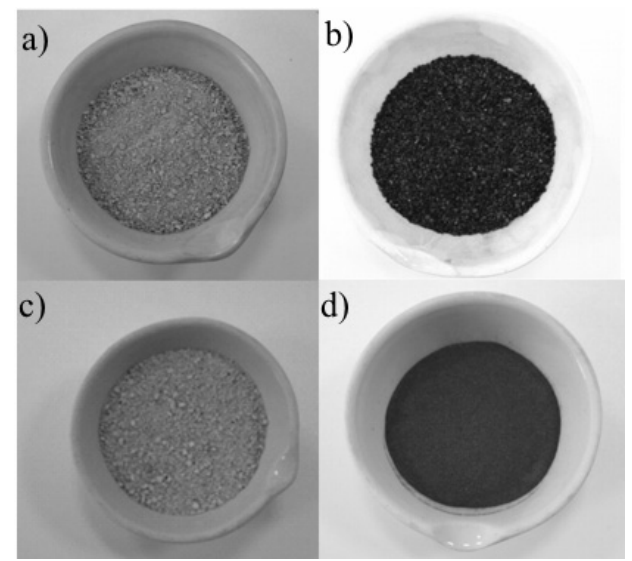

FIGURE 2. Reactive materials used in the research a) geza rock, b) activated carbon, c) zeolite, d) zero-valent iron 
a) geza rock (Wrzosówka/Kielce, Poland),

b) activated carbon (Poland),

c) zeolite (Bystre, Slovakia),

d) zero - valent iron ZVI (H200 Plus ${ }^{\mathrm{TM}}$, HEPURE TECHNOLOGIES USA) .

In laboratory tests as a de-icing agent sodium chloride from PolSuper company was used. Chemical composition of de-icing agent is given in Table 1.

TABLE 1. Chemical composition of de-icing agent

\begin{tabular}{|l|l|}
\hline $\begin{array}{l}\text { Product name of the } \\
\text { de-icing agent }\end{array}$ & Chemical composition \\
\hline $\begin{array}{l}\text { Road salt } \\
\text { Mine Salt "Kłodawa" }\end{array}$ & NaCl min $90.0 \%$ \\
S.A. & $\mathrm{H} 2 \mathrm{O}$ max 3.0\% \\
& $\mathrm{K} 4 \mathrm{Fe}(\mathrm{CN}) 640 \mathrm{ppm}$ \\
\hline
\end{tabular}

\section{METHODS}

The first step of laboratory investigations was the analyze of chloride concentrations in snow samples collected along the streets in Warsaw, which were taken in January and February 2010. Location of sampling sites is presented in Figure 3.

The second step of conducted investigations concentrate on assessment of reactive materials physical properties (sieve analysis, maximum and minimum dry density tests and total specific surface analysis SSA). Tests were conducted according to polish standard (PN-88/B-04481, 1998).

Three types of laboratory retention tests were conducted in the studies. The first was focused on the identification of the chloride reduction ability of the reactive materials. Each of reactive materials $(50 \mathrm{~g})$ was mixed in flasks with $\mathrm{NaCl}$ solution $\left(1500 \mathrm{mg} \cdot \mathrm{dm}^{-3}\right)$ for 48 hours. Chloride concentration, conductivity, $\mathrm{pH}$ and temperature were examined at the beginning and at the end of the experiment. Based on this studies two reactive materials with highest affinity to chloride ions were selected. Thereafter, in pre-

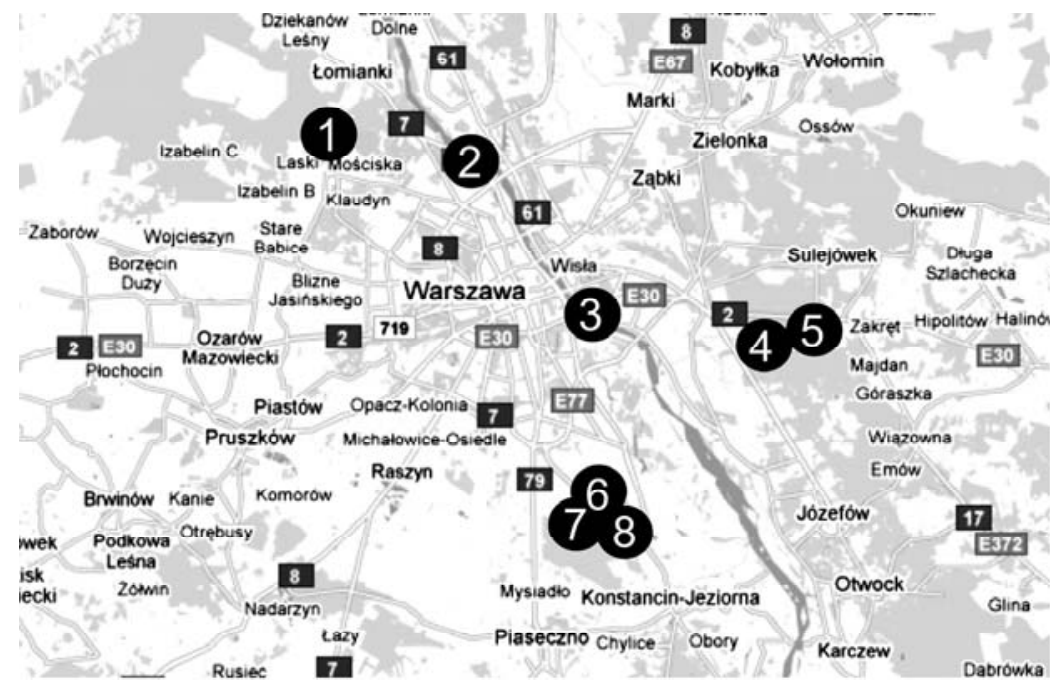

FIGURE 3. Location of sampling sites: 1) Estrady St., 2) Wybrzeże Gdyńskie St., 3) Solec St., 4) Lucerny St., 5) B. Czecha St., 6) Belgradzka Str, 7) Moczydłowska St. 8) Gąsek St. 
vious type of studies on chosen materials batch kinetic tests and batch equilibrium tests were carried out (2nd and 3 rd type of retention studies). These tests were conducted to quantify and qualify the mechanism of chloride uptake by reactive materials. The batch kinetic tests were based on shaking $2 \mathrm{~g}$ of reactive material with $100 \mathrm{ml}$ of $150 \mathrm{mgCl} \cdot \mathrm{dm}^{-3}$ solution for 1, 3, 6, 10, 34 and 58 hours.In batch equilibrium tests variable chloride concentrations $(150,170,190,210,230$ and $250 \mathrm{mg} \cdot \mathrm{dm}^{-3}$ ) and constant shaking period of time $(24 \mathrm{~h})$ were assumed. The concentration, conductivity, $\mathrm{pH}$ and temperature of chloride in the initial and equilibrium solutions were analyzed.

In order to establish the adsorption isotherms were analyzed the batch tests results using Solver program. In parametric analysis following models (adsorption isotherms) were used:

- Freundlich equation

$$
\frac{x}{m}=K_{F} \cdot C_{R}{ }^{N_{F}}
$$

- Langmuir equation:

$$
\begin{aligned}
& \frac{x}{m}=\frac{K_{L} C_{a \max } C_{R}}{1+K_{L} C_{R}} \\
& - \text { Henry equation: } \\
& \frac{x}{m}=K_{D} \cdot C_{R}
\end{aligned}
$$

where: $x / \mathrm{m}$ - the reactive material phase concentration $\left[\mathrm{mg} \cdot \mathrm{g}^{-1}\right], K_{F}, N_{F}-$ Freundlich constants $\left[\mathrm{dm}^{3} \cdot \mathrm{g}^{-1}\right],[-], C_{R}-$ equilibrium concentration of chloride in the liquid phase $\left[\mathrm{mg} \cdot \mathrm{dm}^{-1}\right), K_{L}$ - Langmuir constant $\left[\mathrm{dm}^{3} \cdot \mathrm{g}^{-1}\right], C_{a \text { max }}-$ maximum sorption capacity $\left[\mathrm{mg} \cdot \mathrm{dm}^{-3}\right], K_{D}-$ Henry constant $\left[\mathrm{mg} \cdot \mathrm{dm}^{-3}\right]$.

\section{RESULTS AND DISCUSSION}

\section{Composition of snow samples}

The results of chloride concentration in snow samples are presented in Tables 2 and 3. Chloride concentration depends on the sampling sites (different type of road, traffic density and amount of used de-icing agents) and sampling time

\begin{tabular}{|c|c|c|c|c|}
\hline Sampling place & $\mathrm{pH}$ & $\begin{array}{c}\text { Temperature } \\
{\left[{ }^{\circ} \mathrm{C}\right]}\end{array}$ & $\begin{array}{l}\text { Conductivity } \\
{\left[\mathrm{mS} \cdot \mathrm{cm}^{-1}\right]}\end{array}$ & $\begin{array}{c}\text { Chloride } \\
\text { concentration } \\
{\left[\mathrm{mg} \cdot \mathrm{dm}^{-3}\right]}\end{array}$ \\
\hline Solec St. & 6.84 & 5.1 & 10.71 & 2446.3 \\
\hline Wybrzeże Gdyńskie St. & 7.37 & 6.3 & 22.90 & 6856.6 \\
\hline \multirow{2}{*}{ Estrady St. } & 8.37 & 6.7 & 4.32 & 999.8 \\
\hline & 8.28 & 10.1 & 5.58 & 1297.6 \\
\hline \multirow{2}{*}{ Belgradzka St. } & 8.16 & 8.9 & 12.87 & 3148.2 \\
\hline & 7.57 & 5.6 & 8.07 & 1808.1 \\
\hline Gąsek St. & 7.65 & 10.1 & 8.38 & 2063.4 \\
\hline Moczydłowska St. & 8.14 & 8.5 & 13.83 & 4112.6 \\
\hline
\end{tabular}
(heavy snowfalls and low temperature in first sampling time, low snowfalls

TABLE 2. Analysis of snow samples - January 2010 
TABLE 3. Analysis of snow samples - February 2010

\begin{tabular}{|c|c|c|c|c|}
\hline Sampling place & $\mathrm{pH}$ & $\begin{array}{c}\text { Temperature } \\
{\left[{ }^{\circ} \mathrm{C}\right]}\end{array}$ & $\begin{array}{l}\text { Conductivity } \\
{\left[\mathrm{mS} \cdot \mathrm{cm}^{-1}\right]}\end{array}$ & $\begin{array}{c}\text { Chloride } \\
\text { concentration } \\
{\left[\mathrm{mg} \cdot \mathrm{dm}^{-3}\right]}\end{array}$ \\
\hline Solec St. & 7.80 & 17.0 & 106 & 10.63 \\
\hline Wybrzeże Gdyńskie St. & 7.51 & 16.7 & 157 & 3.55 \\
\hline Estrady St. & 7.64 & 16.4 & 71 & 7.09 \\
\hline Lucerny St. & 7.46 & 16.5 & 151 & 28.36 \\
\hline B. Czecha St. & 7.47 & 16.4 & 101 & 26.94 \\
\hline Belgradzka St. & 7.37 & 16.4 & 118 & 11.35 \\
\hline Gąsek St. & 7.20 & 16.4 & 81 & 19.85 \\
\hline Moczydłowska St. & 7.51 & 16.4 & 65 & 10.64 \\
\hline
\end{tabular}

and higher temperature in the second sampling time). The analyses of snow samples indicated a large difference in chloride concentrations between January and February. The samples from February were collected two weeks after single snowfall, therefore the lower chloride concentrations were detected. However, during this period single road de-icing was applied. The samples col- lected in January were taken six weeks after first snowfall. During this time numerous snowfalls and frequent de-icing of roads were observed.

\section{Physical properties}

The grain size distribution of tested reactive materials are shown in Figure 4 whereas maximum and minimum dry

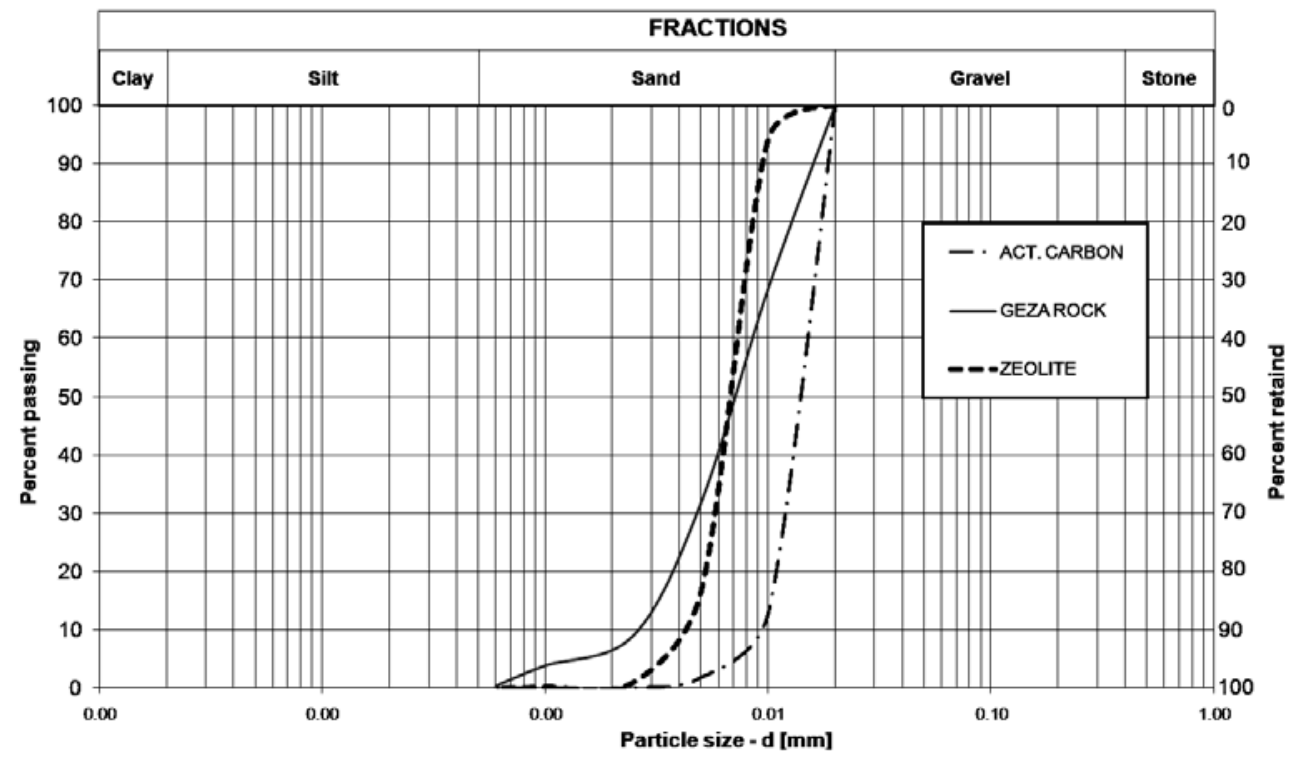

FIGURE 4. Grain size distribution of reactive materials 
density are presented in Table 4. The highest maximum dry density has zero-valent iron and the lowest - activated carbon. Results of total SSA (Tab. 5) showed that the highest SSA has activated carbon and zero-valent iron. The smallest SSA was determined for geza rock

\section{Retention tests}

The first type of retention tests have shown, that all tested reactive materials reduce chloride concentration, but the most effective are activated carbon and zero-valent iron. This two reactive materials, widely used in PRB technology, were chosen for further retention tests (Tab. 6).

In 3rd type of retention tests equilibrium times, assumed on the bases of batch kinetic tests, were: 24 hours for activated carbon and 48 hours for zero-valent iron (Fig. 5).

TABLE 4. Maximum and minimum dry densities of reactive materials

\begin{tabular}{|l|l|l|}
\hline Reactive material & $\rho_{\mathrm{d}} \min \left[\mathrm{t} \cdot \mathrm{m}^{-3}\right]$ & $\rho_{\mathrm{d}} \max \left[\mathrm{t} \cdot \mathrm{m}^{-3}\right]$ \\
\hline Activated carbon & 0.370 & 0.527 \\
\hline Geza rock & 1.410 & 2.258 \\
\hline Zeolite & 0.867 & 1.230 \\
\hline Zero - valent iron & 2.760 & 4.879 \\
\hline
\end{tabular}

TABLE 5. Specific surface areas of reactive materials

\begin{tabular}{|l|c|c|c|}
\hline Material & Dry mass $[\mathrm{g}]$ & MBC & $\begin{array}{c}\text { Specific surface area } \\
{\left[\mathrm{m}^{-2} \cdot \mathrm{g}\right]}\end{array}$ \\
\hline Activated carbon & 10.00 & 9.63 & 201.61 \\
\hline Geza rock & 10.00 & 0.12 & 2.47 \\
\hline Zeolite & 10.00 & 1.59 & 33.34 \\
\hline Zero - valent iron & 10.00 & 4.21 & 77.26 \\
\hline
\end{tabular}

TABLE 6. Effectiveness of chloride reduction

\begin{tabular}{|l|c|c|c|c|c|c|c|c|}
\hline \multirow{4}{*}{ Material } & \multicolumn{2}{|c|}{$\begin{array}{c}\text { Chloride } \\
\text { concentration } \\
{\left[\mathrm{mg} \cdot \mathrm{dm}^{-3}\right]}\end{array}$} & \multicolumn{2}{|c|}{$\mathrm{pH}$} & \multicolumn{2}{c|}{$\begin{array}{c}\text { Conductivity } \\
{\left[\mathrm{mS} \cdot \mathrm{cm}^{-1}\right]}\end{array}$} & \multicolumn{2}{c|}{ Temperature $\left[{ }^{\circ} \mathrm{C}\right]$} \\
\cline { 2 - 11 } & initial & final & initial & final & inital & final & initial & final \\
\hline \multirow{3}{*}{ Activated carbon } & 1529.13 & 758.69 & 10.27 & 10.85 & 3.68 & 4.62 & 20.6 & 15.1 \\
\cline { 2 - 11 } & 1529.13 & 957.23 & 10.25 & 10.41 & 3.71 & 4.10 & 20.8 & 14.9 \\
\hline \multirow{2}{*}{ Geza } & 1529.13 & 1269.21 & 8.28 & 7.23 & 4.59 & 4.63 & 20.5 & 15.2 \\
\cline { 2 - 11 } & 1529.13 & 1028.22 & 8.57 & 7.75 & 3.11 & 4.79 & 20.6 & 15.2 \\
\hline \multirow{2}{*}{ Zeolite } & 1529.13 & 1198.31 & 7.32 & 7.36 & 4.54 & 4.56 & 20.0 & 14.7 \\
\cline { 2 - 10 } & 1529.13 & 1191.22 & 6.73 & 7.13 & 4.00 & 4.66 & 20.0 & 15.1 \\
\hline \multirow{2}{*}{ Zero- valent iron } & 1529.13 & 1198.31 & 6.47 & 9.59 & 3.90 & 4.51 & 20.8 & 15.3 \\
\cline { 2 - 10 } & 1529.13 & 1035.22 & 8.48 & 9.68 & 3.58 & 4.54 & 20.2 & 15.4 \\
\hline
\end{tabular}




\section{Kinetic of chloride uptake on activated carbon and zero-valent iron}

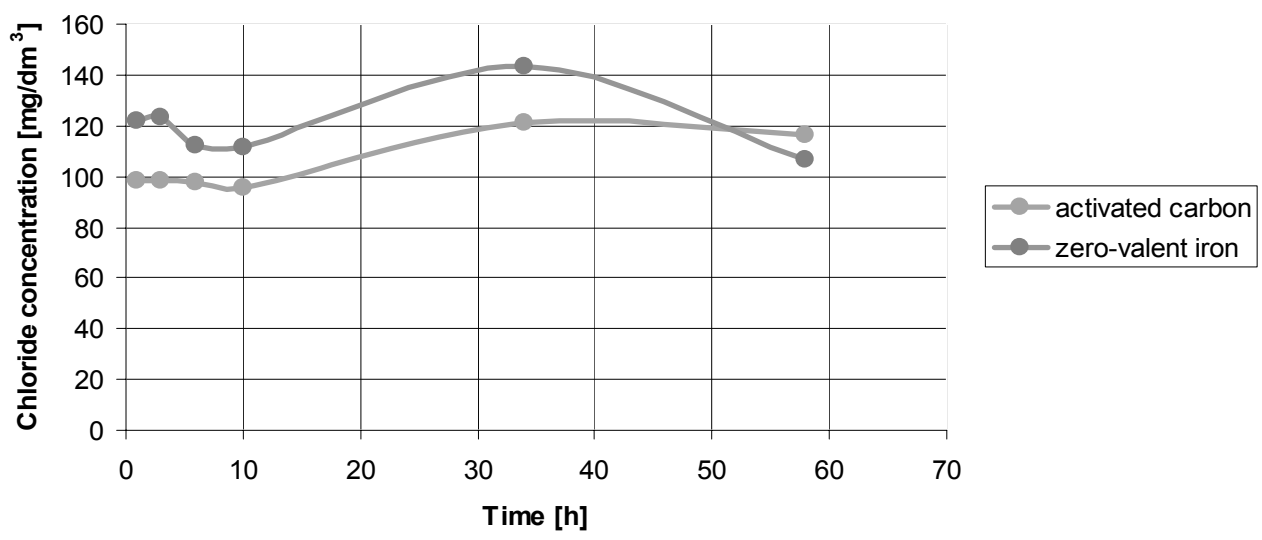

FIGURE 5. Kinetic of chloride uptake on activated carbon and zero-valent iron

Results of batch equilibrium tests for activated carbon and zero-valet iron are presented in Table 7 and 8, whereas Freundlich adsorption isotherms are shown in Figure 6. Both materials tested reduce chloride concentration but with low intensity. However, these materials are widely used as reactive materials fulfilling PRBs, and presumably they have ability to heavy metals and organic compounds retention, also in the vicinity of roads. Therefore, it is important to examine, whether this materials are suitable to minimize the salt concentration in runoff water from roads.

In calculations Langmuir isotherms could not been used. Langmuir equation is intended for low concentrations of substances in solution. Presumably initial chloride concentrations exceeded the applicability of the Langmuir model. As in the previous case, Henry equation, also have not resulted in gratifying fitting: for activated carbon $\mathrm{R}^{2}$ is 0.45 whereas parameter of Henry isotherm for zero-valent iron could not been es-

TABLE 7. Results of batch equilibrium tests for activated carbon (Michniak 2010)

\begin{tabular}{|c|c|c|c|c|}
\hline \multirow{2}{*}{$\begin{array}{l}\text { Sample } \\
\text { number }\end{array}$} & \multicolumn{2}{|c|}{ Conductivity $\left[\mathrm{mS} \cdot \mathrm{cm}^{-1}\right]$} & \multirow{2}{*}{$\begin{array}{c}\text { Initial chloride } \\
\text { concentration }\left[\mathrm{mg} \cdot \mathrm{dm}^{-3}\right]\end{array}$} & $\begin{array}{c}\text { Equilibrium chloride } \\
\text { concentration }\left[\mathrm{mg} \cdot \mathrm{dm}^{-3}\right]\end{array}$ \\
\cline { 2 - 3 } & Initial & Equilibrium & 150 & 143.23 \\
\hline 1 & 652 & 674 & 170 & 159.54 \\
\hline 2 & 696 & 719 & 190 & 180.81 \\
\hline 3 & 736 & 845 & 210 & 190.74 \\
\hline 4 & 817 & 874 & 230 & 212.01 \\
\hline 5 & 1150 & 945 & 250 & 221.23 \\
\hline 6 & 970 & 986 & & \\
\hline
\end{tabular}


TABLE 8. Results of batch equilibrium tests for zero-valent iron (Michniak 2010)

\begin{tabular}{|c|c|c|c|c|}
\hline \multirow{2}{*}{$\begin{array}{l}\text { Sample } \\
\text { number }\end{array}$} & \multicolumn{2}{|c|}{ Conductivity $\left[\mathrm{mS} \cdot \mathrm{cm}^{-1}\right]$} & $\begin{array}{c}\text { Initial chloride } \\
\text { concentration }\left[\mathrm{mg} \cdot \mathrm{dm}^{-3}\right]\end{array}$ & $\begin{array}{c}\text { Equilibrium chloride } \\
\text { concentration }\left[\mathrm{mg} \cdot \mathrm{dm}^{-3}\right]\end{array}$ \\
\cline { 2 - 3 } & initial & final & 150 & 146.61 \\
\hline 1 & 560 & 563 & 170 & 163.37 \\
\hline 2 & 598 & 609 & 190 & 183.65 \\
\hline 3 & 721 & 722 & 210 & 204.21 \\
\hline 4 & 754 & 763 & 230 & 222.64 \\
\hline 5 & 875 & 771 & 250 & 238.70 \\
\hline 6 & 990 & 1009 & & \\
\hline
\end{tabular}

Freundlich isotherm activated carbon

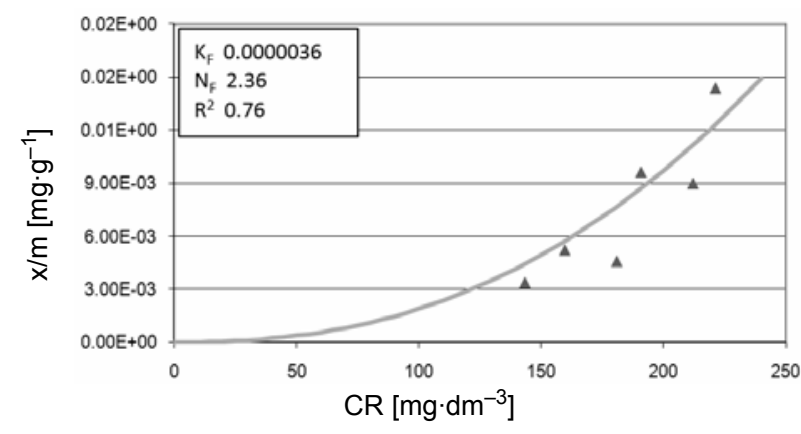

A results calculated Freundlich

Freundlich isotherm zero-valent iron

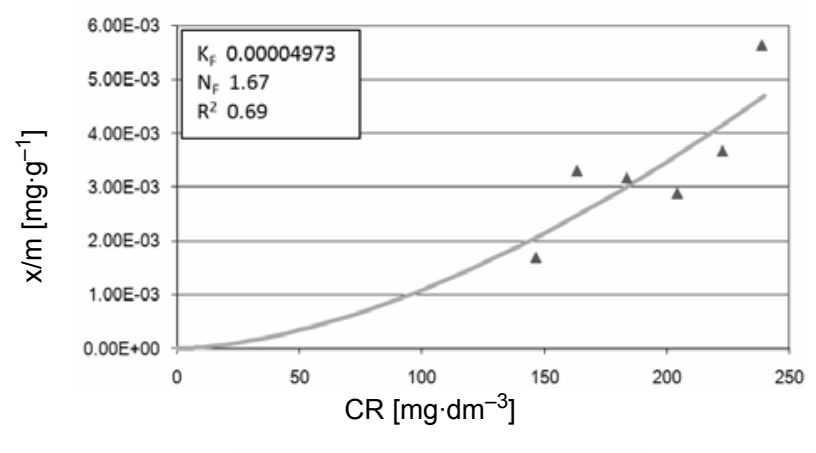

A results calculated Freundlich

FIGURE 6. Freundlich isotherm (Michniak 2010)

tablished because is dedicate for linear relationship. In test results interpretation the Freundlich equation was used. This model in comparison to mentioned modtion mechanism on the surface of tested materials. However, it is important to els, accurately describes chloride retenseek a better models for describe this retention processes. 


\section{CONCLUSIONS}

The development of road infrastructure is closely linked to the level of environmental pollution in Poland. It is therefore of great importance to develop technology, which use can reduce the concentration of contaminants generated of road by transportation facilities, particularly in the most ecologically valuable areas. The application of (multilayer) Permeable Reactive Barriers filled with reactive materials promises the achievement of good results. However, chosen reactive materials should be able to reduce a wide range of contaminants with various physicochemical properties.

Results of conducted investigations showed that chloride concentration in snow samples is considerably varied even on the same sampling sites. These differences are dependent on sampling time, frequency and intensity of snowfalls. These factors are closely affected by the amount of salt used to ensure safe driving conditions.

Basic and effective studies applied in determining the suitability of reactive materials for the retention of pollutants are batch tests. On the basis of these tests, it can be concluded, that activated carbon and zero-valent iron seem to be the best materials (activated carbon, zeolite, zero-valent iron, geza rock) for the reduction of chlorides. They are commonly used in PRBs as reactive materials causing reduction of several types of contaminants e.g. heavy metals and organic compounds. Therefore, it is reasonable to conduct further studies demonstrating the applicability of these materials as fillers PRBs in the vicinity of roads.

\section{Acknowledgments}

This research was supported by Grant no. NN523 561638 from Ministry of Science and Higher Education. Warsaw. Poland

\section{REFERENCES}

CEKSTERE G., NIKODEMUS O., OSVALDE A. 2008: Toxic impact of de-icing material to street greenery in Riga, Latvia. Elseviewer; Urban Forestry and Urban Greening, vol. 7, no 3: 207-217.

DANIEL D.E. 1994: State-of-the-art: laboratory hydraulic conductivity tests for saturated soils. Hydraulic conductivity and waste contaminant transport in soil. ASTM STP 1142, ASCE: $30-78$.

DzU 2002:165.1359. Regulation of the Minister of the Natural Environment on soil quality 9.09.2002. (in Polish).

EPA/530/SW-87-006-F 1992. ROY W.R., KRAPAC I.G., CHOU S.F.J., GRIFFIN R.A. 1992: Batch-Type Procedures For Estimating Soil Adsorption of Chemicals. U.S. Government Printing Office.

EPA 542-F-01-005 2001: A Citizen's Guide to Permeable Reactive Barriers. U.S. Government Printing Office.

FRONCZYK J. 2008: Zeolite-sand mixtures in permeable reactive barriers in landfill's surrounding. Doctoral thesis, Department of Geotechnical Engineering, WULS, Warsaw (in Polish).

Road and Bridge Research Institute, 2006: Guidelines for winter road maintenance. Warsaw (in Polish).

MERKISZ J., PIEKARSKI W., SŁOWIK T. 2005: Automotive pollution of the environment. AR Publisher, Lublin (in Polish).

MICHNIAK M. 2010: Application of Permeable Reactive Barriers near roads for chloride ions removal. MSc thesis WULS, Warsaw.

PN-88/B-04481. 1998: Building soils. Laboratory tests. Alfa Publisher. Warsaw. 
POLKOWSKA Ż., DUBIELLA-JACKOWSKA A., ZABIEGAŁA B., NAMIEŚNIK J. 2007: Composition of pollutants in the water samples collected along the highways with different traffic intensity. Ecological Chemistry and Engineering, vol. 14, no 3: 315-338 (in Polish).

YONG R.N., MULLIGAN C.N. 2004: Natural attenuation of contaminants in soils. Lewis Publishers. USA.

Streszczenie: Zastosowanie Przepuszczalnych Barier Reaktywnych przy drogach do usuwania jonów chlorkowych. Do poważniejszych źródeł zanieczyszczenia środowiska gruntowo-wodnego należą wody spływowe z dróg, które są mieszaniną substancji szkodliwych, złożoną m.in. z metali ciężkich, związków stosowanych do odladzania, związków organicznych i zawiesin. Powszechnie stosowaną substancją do odladzania nawierzchni jest negatywnie oddziaływujący na środowisko chlorek sodu. W przypadku nieprawidłowego zabezpieczenia środowiska gruntowo-wodnego wzdłuż dróg zanieczyszczenia mogą migrować do wód gruntowych, powodując zagrożenie dla źródeł wody pitnej. Jedną z metod zapobiegania tym zjawiskom jest wymuszony przepływ zanieczyszczeń przez materiały reaktywne wypełniające przepuszczalną barierę reaktywną (PRB).Celem badań jest zbadanie przydatności wybranych materiałów reaktywnych do zmniejszenia stężenia chlorków w wodach spływowych $z$ dróg. W artykule przedstawiono analizę czterech materiałów reaktywnych pod kątem usuwania chlorków. Wyniki badań wskazują na to, że materiały, które są najpowszechniej wbudowywane w PRBs - wegiel aktywny i żelazo elementarne, usuwają największą ilość tych zanieczyszczeń. Ponadto, w ramach badań, zbadano skład chemiczny próbek śniegu pobranych wzdłuż dróg w Warszawie.

Stowa kluczowe: Przepuszczalne Bariery Reaktywne, materiały reaktywne, oczyszczanie, zanieczyszczenia, środki do odladzania.

MS. received November 15, 2010

\author{
Authors' address: \\ Katedra Geoinżynierii SGGW \\ 02-776 Warszawa. ul. Nowoursynowska 159 \\ Poland \\ e-mail: joanna_fronczyk@sggw.pl \\ katarzyna_pawluk@sggw.pl \\ michniak.marta@gmail.com
}

